\title{
Borsa Şirketlerinin Pay Geri Alım İşlemlerine Yönelik TMS/TFRS Uygulamaları*
}

\author{
Burak PİRGAIP** \\ Semra KARACAER ${ }^{* * *}$
}

\section{ÖZET}

Pay geri alımları, uluslararası arenada borsa şirketlerinin, özellikle pay değerlerinin aşırı düştüğ̈̈ dönemlerde, paylarının gerçek değeri hakkında piyasaya mesaj vererek düşük fiyatlamanın önüne geçmek amacıyla başvurduğu yöntemlerden biri olagelmiştir. Türkiye'de ise pay geri alımları Türk Ticaret Kanunu ve Sermaye Piyasası Kanunu'nda son dönemde yapılan değişikliklerle mevzuata kazandırlmış, borsa şirketlerine belirli şartlar altında bu tür işlemlerde bulunabilme imkânı getirilmiştir. Diğer taraftan, şirketlerin bu imkândan yararlanabilmelerinin, pay geri alım işlemlerinin şirketin kendisi de dâhil olmak üzere başta yatırımcıları olmak üzere tüm paydaşları üzerindeki etkilerinin farkında olmalarına bağll olduğu düşünülmektedir. Bu kapsamda, çalışmanın amacı pay geri alım işlemlerinin etkilerinin finansal tablolar açısından değerlendirilmesi olarak belirlenmişs olup, çalışmada Türkiye Muhasebe Standartları (TMS/ Türkiye Finansal Raporlama Standartları (TFRS)'nın konuya iliş̧kin hükümleri örnek uygulamalarla desteklenmek suretiyle detayll olarak irdelenmekte ve uygulamaya yönelik önerilere yer verilmektedir.

Anahtar Kelimeler: Pay geri alımlar, Türkiye Muhasebe Standartlarl, Türkiye Finansal Raporlama Standartlart.

JEL Sinıflandirması: M40, M41, M49.

\section{Share Repurchase Transactions in TAS/TFRS: An Implementation Guidance for Listed Companies}

\section{ABSTRACT}

Share repurchase in the international arena has been one of the means for listed companies for years to avoid undervaluation by signalling the fair value of their shares to the market. Turkey, however, has recently updated its legal infrastructure in both Commercial Code and Capital Markets Law in order for listed companies to grasp the benefits of such transactions provided that several criteria are met. On the other hand, companies are in need of comprehending the basic effects of share repurchase transactions not only on stakeholders but also on themselves. Hence, this study has the purpose to interpret these effects in a financial reporting point of view in accordance with Turkish Accounting Standards (TAS)/Turkish Financial Reporting Standards (TFRS) and provide an implementation guiadance with illustrative examples and supporting recommendations as well.

Keywords: Share repurchase, Turkish Accounting Standards, Turkish Financial Reporting Standards.

Jel Classification: M40, M41, M49.

\footnotetext{
* Bu çalışma Hacettepe Üniversitesi Sosyal Bilimler Enstitüsü tarafindan kabul edilen "Pay Geri Alımları ile Geri Alım İşlemlerinin Neden ve Sonuçlarının Analizi: Borsa İstanbul Üzerine Bir Uygulama” başlıklı doktora tezinden yararlanılarak hazırlanmıştır.

** Dr. Burak PİRGAİP, Sermaye Piyasası Kurulu Başuzmanı, burak.pirgaip@spk.gov.tr

**** Prof. Dr. Semra KARACAER, Hacettepe Üniversitesi, İktisadî ve İdarî Bilimler Fakültesi, İşletme Bölümü semra@hacettepe.edu.tr
} 


\section{GíRİş}

Şirketlerin daha önceden ihraç edilmiş paylarını ortaklarından satın alması olarak kavramsallaştırılabilecek pay geri alım işlemleri birçok ülkede yaygın bir uygulama alanı bulmaktadır. $\mathrm{Bu}$ uygulamaların başında ise borsada gerçekleştirilen pay geri alımları gelmektedir ${ }^{1}$. Bu şekilde gerçekleștirilen geri alımlar örneğin ABD'de 2004, 2005 ve 2006 yıllarında sırasıyla 197 milyar \$, 349 milyar \$ ve 437 milyar \$ tutarına ulaşmış (MacGuigan vd., 2009: 528); 2006 yılı itibarıla Birleşik Krallık’ta 46 milyar $£$ (Dhanani ve Roberts, 2009: VII). Almanya'da ve Fransa'da ise, sirasiyla, 3.5 milyar $€$ ve 6.2 milyar $€$ olarak gerçekleşmiştir (Mieczysław, 2011:50). Kanada'da, bu işlemlerin 1985 yılında 429 milyon \$ olan tutarı 2003 yılında 3.3 milyar \$'a yükselmiştir (Kooli ve L'Her, 2010).

Japonya, Hong Kong, Tayland gibi Uzak Doğu; İsveç, Danimarka, Norveç gibi İskandinav ve Brezilya, Meksika gibi Latin Amerika ülke piyasalarında da imkân tanınan pay geri alım işlemleri, Türkiye'de, ancak 6102 sayılı Türk Ticaret Kanunu'nun 2012 yılı ortalarında hayata geçmesiyle birlikte başta anonim şirketler olmak üzere tüm sermaye şirketlerini kapsayacak şekilde yasal dayanağa kavuşturulabilmiştir ${ }^{2}$. Borsa şirketlerinin pay geri alım işlemlerine ilişkin özel uygulama esasları ise 6362 sayılı Sermaye Piyasası Kanunu ve Sermaye Piyasası Kurulu'nun (SPK) ikincil düzenlemeleriyle belirlenmiştir ${ }^{3}$.

Türkiye'de borsa şirketlerinin Kamu Gözetimi Muhasebe ve Denetim Standartları Kurumu tarafindan yayımlanan TMS/TFRS (IAS/IFRS) ${ }^{4}$ ye göre finansal raporlama yapmalarının zorunlu olması nedeniyle, pay geri alım işlemlerinin de finansal tablolara etkisinin söz konusu standartlar kapsamında değerlendirilmesi gerekmektedir.

\section{TMS/TFRS ÇERÇEVESINDE PAY GERİ ALIMLARI}

\subsection{Pay Geri Alım İşlemlerinin Raporlanmasında Temel İşlemler}

Yöneticiler pay fiyatlarının düşük değerlendiği kanaatinde olduklarında şirketlerinin paylarını bir yatırım alternatifi olarak görebilmektedir. Bu bakımdan, geri alınan payların

\footnotetext{
${ }^{1}$ Söz konusu yöntemlerin başlıcalarını borsada gerçekleştirilen geri alımlar, çağrı yoluyla geri alımlar, müzakere yoluyla geri alımlar ve sentetik geri alımlar oluşturmaktadır.

${ }^{2} 6102$ sayılı Türk Ticaret Kanunu 14.02.2011 tarihinde yayımlanmış; yürürlük tarihi ise 01.07.2012 olarak tespit edilmiştir. 6762 sayılı mülga Türk Ticaret Kanunu'nun 329. maddesinde şirketlerin kendi paylarını geri alamayacağ1, bu sonucu doğuran sözleşmelerin hükümsüz olacağı kesin bir dille ifade edilmiştir. Bununla birlikte, hukukî ve ekonomik gereklilikler karşısında uygulamanın bu kesin yasak hükmüne mahkûm edilmemesi amacıyla, maddede sınırlı sayıda istisna hükmü öngörülmüştür. Bu nedenle, Türkiye'de pay geri alımları uzun yıllar istisnaî bir uygulama olarak değerlendirilmiştir.

${ }^{3}$ Sermaye piyasası mevzuatında pay geri alımları ilk olarak SPK'nın 2009 ve 2011 yıllarında aldığı iki ayrı ilke kararıyla (01.09.2009 tarih ve 27/748 sayılı karar - 2009/39 sayılı SPK Haftalık Bülteni) ve 10.08.2011 tarih ve 26/767 sayılı karar - 2011/32 sayılı SPK Haftalık Bülteni) düzenlenmiş; aradan geçen süre zarfında 30.12.2012 tarihinde yürürlüğe giren 6362 sayılı Sermaye Piyasası Kanunu ve 03.01.2014 tarihinde yürürlüğe giren II-22.1 Geri Alınan Paylar Tebliği ile pay geri alımı işlemlerinin sermaye piyasası boyutu şekillenmiştir.

4 TMS/TFRS, Uluslararası Muhasebe Standartları Kurulu tarafindan yayımlanan Uluslararası Muhasebe Standartları (IAS) ve Uluslararası Finansal Raporlama Standartları (IFRS) ile uyumludur.
} 
bilânçoda varlıklar arasında gösterilmesinin mümkün olduğu ileri sürülebilir. TMS/TFRS'nin bu konudaki yaklaşımı ise, geri alınan payların varlık olarak muhasebeleştirilmesinin mümkün olmadığı [IFRS 2: Basis for Conclusions BC332 ve BC333 ile TMS/IAS 39 "Finansal Araçlar: Muhasebeleştirme ve Ölçme" (Financial Instruments: Recognition and Measurement), UR/AG97]; aksi takdirde konu hakkındaki kavramsal çerçeve hükümlerine aykırılık oluşacağ ${ }^{5}$ yönündedir.

TMS/TFRS'ye göre pay geri alımları şeklen şirket ile ortakları arasında gerçekleştirilen işlemler olsa da, özü itibarıyla, şirketin ortakları arasında gerçekleştirilen işlemlerdir (IFRS 2: Basis for Conclusions, BC73 ve BC331). Sonuçta şirket, ortakların bir araya gelerek koydukları öz kaynak ile birtakım ortaklardan paylarını geri almakta, dolayısıyla ortaklar arasında, kalan ortakların yatırımları, satan ortakların ise ortaklıkları azalacak şekilde, karşılıklı bir işlem gerçekleştirilmiş olmaktadır. Konuyla ilgili olarak TMS/IAS 32 - "Finansal Araçlar: Sunum" (Financial Instruments: Presentation) standardı ile standarda ait uygulama rehberinde:

(1) "Şirketler tarafından geri alınan payların öz kaynak grubu içerisinde öz kaynaklardan bir indirim olarak gösterileceği”" (TMS/IAS 32: Para. 33),

(2) "Pay geri alım işlemleri ile geri alınan paylarla ilgili diğer işlemlerin gelir tablosuna yansitılamayacağı" (TMS/IAS 32: Para. 33),

(3) "Pay bedellerinin doğrudan öz kaynaklar içinde muhasebeleştirileceği" (TMS/IAS 32: Para. 33),

(4) "Pay tutarlarının bilânçoda ayrı gösterime tâbi tutulmak veya dipnotlarda ayrıca yer verilmek suretiyle kamuya açıklanacağı” (TMS/IAS 32: Para. 34),

(5) "Geri alınan payların hiçbir şekilde finansal varlık olarak muhasebeleştirilemeyeceği”" (TMS/IAS 32: UR/AG36) ve

(6) "Şirketle arasında vekâlet ilişkisi bulunan taraflar adına geri alınan payların finansal tablolarla ilişkilendirilemeyeceği" (TMS/IAS 32: UR/AG36) ${ }^{6}$ ifade edilmiştir.

$\mathrm{Bu}$ hükümler uyarınca, geri alınan paylar, varlık tanımının unsurları arasında sayılan ekonomik fayda girişi beklentisini [TMS/TFRS (IAS/IFRS) - "Finansal Raporlamaya İlişkin Kavramsal Çerçeve (The Conceptual Framework for Financial Reporting), Para. 4.4 ve 4.44] karşılamaması nedeniyle bilânçoda finansal varlık olarak gösterilememekte; ilgili işlemler ise, gelirin (giderin) varlıklardaki bir artışın (azalışın) etkisiyle ekonomik fayda girişi (çıkışı) beklentisinin oluşması hâlinde tahakkuk etmesi [TMS/TFRS (IAS/IFRS) - "Finansal

\footnotetext{
${ }^{5}$ Ekonomik etkinin finansal tablolara doğru yansttllabilmesi, TMS/TFRS (IAS/IFRS) - "Finansal Raporlamaya İlişkin Kavramsal Çerçeve (The Conceptual Framework for Financial Reporting) standardında faydalı bilginin nitelikleri arasında sayılmış (NÖ/QC12), bir kalemin varlık veya öz kaynak tanımı kapsamında yer alıp almadığının tespitinde hukukî şekilden ziyade kalemin ekonomik anlamına bakılması gerektiği ayrıca ifade edilmiştir (Para. 4.6).

${ }^{6}$ Örneğin, bir aracı kurumun aracılık sözleşmesi kapsamında müşterisinin portföyüne aracı kurumun paylarından satın alması hâlinde, aracı kurumun geri aldığı bu payları finansal tablolarıyla ilişkilendirmesi mümkün bulunmamaktadır.
} 
Raporlamaya İlişkin Kavramsal Çerçeve (The Conceptual Framework for Financial Reporting), Para. 4.47 ve 4.49] nedeniyle gelir tablosuyla ilişkilendirilememektedir.

$\mathrm{Bu}$ kapsamda, ekonomik etkinin finansal tablolarda doğru yansitılabilmesi açısından geri alınan payların ve ödenen pay bedellerinin, şirket ile ortaklar arasında gerçekleştirilen ortaklık haklarıyla bağlantılı tüm işlemlerde olduğu gibi ${ }^{7}$, öz kaynakla ilişkilendirilmesi gerekmektedir ${ }^{8}$. Buna göre, pay geri alım işlemi sonucunda ihraç edilmiş bulunan pay sayısında bir değişiklik olmamakla birlikte, dolaşımdaki pay sayısı ve öz kaynak toplamı düşmektedir.

TMS/TFRS uyarınca, geri alınan payların bilânçoda varlık olarak değil öz kaynaklardan indirilerek gösterilmesi, dolayısıyla geri alım işlemleri sonucunda bilânçonun hem varlık (nakit çıkışı nedeniyle) hem de öz kaynak (geri alınan payların gösterimi nedeniyle) tarafında küçülmesi gerekmektedir.

Diğer taraftan, TMS/TFRS geri alım işlemleriyle ilgili bilginin bilânçoda veya dipnotlarda ayrı açıklamaya tâbi tutulmasını zorunlu tutmakla birlikte, muhasebeleştirmenin nasıl yapılacağ 1 hususunda genel ilkelere yer vermekle yetinmekte, muhasebeleştirmede kullanılacak yöntemleri düzenleyici otoritelere ve finansal tablo hazırlayan kesimlere birakmaktadır.

Bu noktada, ABD Genel Kabul Görmüş Muhasebe İlkeleri’nin (US GAAP) konuyla ilgili uygulama kurallarının (Epstein ve Jermakowicz, 2008: 696) dikkate alınmasında fayda görülmektedir. Söz konusu uygulama kuralları kapsamında pay geri alım işlemleri, maliyet yöntemi, nominal değer yöntemi ve geri çekilmiş sayma yöntemi olmak üzere üç yöntem takip edilerek muhasebeleştirilebilmekte olup, her üç yöntemde de geri alınan paylar ve ilgili işlemler öz kaynakla ilişkilendirildiği için TMS/TFRS uyarınca kabul edilebilir yöntemler olarak değerlendirilmektedir (Stickney vd., 2009: 678).

\subsubsection{Pay Geri Alım İşlemlerinin Muhasebeleştirilmesi}

\subsubsection{Maliyet Yöntemi (Cost Method)}

Maliyet yönteminin temel özelliği, geri alınan paylar daha önce ihraç edildiğinde oluşturulmuş bulunan ana hesapları (sermaye, pay ihraç primi) etkilememesidir. Bir başka deyişle, geri alınan payların ihracına ilişkin ilk hesaplar aynen muhafaza edilmektedir. $\mathrm{Bu}$ yaklaşım geri alım işleminin, özünde ortaklar arası bir işlem olması özelliğiyle tutarlılık arz etmektedir (Flood, 2014: 576).

\footnotetext{
${ }^{7}$ Şirket ile ortaklar arasında gerçekleştirilen ortaklık haklarıyla bağlantılı işlemlere kâr dağııımı ve sermaye artırımı örnek olarak gösterilebilir. Geri alım işleminin kâr dağııımının bir alternatifi olması ve teknik anlamda sermaye artırımının tersi sonuçlar doğurması, ortaklık haklarıyla bağlantısına işaret etmektedir.

${ }^{8}$ IAS/IFRS'nin benimsediği bu yaklaşım US GAAP uygulamalarıyla da paralellik arz etmektedir. Konuyla ilgili US GAAP'in kodu $\quad 505.30 \quad$ olup, metnine https://law.resource.org/pub/us/code/bean/fasb.html/fasb.505.2011.html linkinden ulaşılabilmektedir.
} 
Yöntemde ana hesaplar yerine, geri alınan paylara özgü yeni bir öz kaynaktan indirim kalemi yaratılmakta ve geri alınan paylar alış maliyeti üzerinden bu hesaba kaydedilmektedir. Geri alınan payların daha sonra tekrar satışından elde edilen kayıp/kazançların öz kaynakta muhasebeleştirilmesinde ise, geri alınan paylar, alış maliyetinden yüksek bir fiyatla elden çıkarılıyorsa, sanki yeni bir pay ihracı yapılıyormuş gibi, geri alınan paylara özgü bir pay ihraç primi hesabı alacaklandırılmaktadır. Payların alış maliyetinden düşük bir fiyatla elden çıkarılması hâlinde de, daha önceden açılmışsa söz konusu hesap borçlandırılmakta, açılmamışsa veya aşan kısım varsa ilgili tutarlar geçmiş yıl zararı olarak kaydedilmektedir.

Diğer taraftan, birden fazla işlemle pay geri alımı yapılmışsa, bu payların elden çıkarılması aşamasında doğru kayıtların yapılabilmesi için ilk giren ilk çıkar, ortalama gibi uygun yaklaşımlarla, alınan ve satılan paylar arasında tahminî veya daha sık takip yapılmak suretiyle birebir ilişki kurulması gerekmektedir.

\subsubsection{Nominal Değer Yöntemi (Nominal Value Method)}

Nominal değer yönteminde de, maliyet yönteminde olduğu gibi geri alınan paylara özgü bir öz kaynaktan indirim kalemi yaratılmakta; ancak, geri alınan paylar bu hesaba nominal değeriyle kaydedilmektedir. Alış maliyeti ile nominal değer arasındaki fark ise bu paylar ihraç edildiğinde muhasebeleştirilmiş bulunan ana hesaplarla ilişkilendirilmektedir. Buna göre, alış bedeli geri alınan payların ilk ihracında elde edilen bedelden fazla ise, pay ihraç primleri hesabı ilgili tutar kadar borçlandırıldıktan sonra kalan kısım için geçmiş yıl zararı hesabı çalıştırılmakta; az ise, pay ihraç primleri hesabı borçlandırılıp, geri alınan paylara özgü bir pay ihraç primi hesabı alacaklandırılmaktadır.

Diğer taraftan, geri alınan paylar elden çıkarıldığında, bu paylar ilk defa ihraç edildiği gibi muhasebeleştirme yapılmaktadır. Yöntem bu yönüyle de maliyet yönteminden ayrılmaktadır; çünkü, maliyet yönteminde, geri alınan payların satışında yalnızca geri alım işlemlerine özgü hesaplar işletilirken, nominal değer yönteminde paylar yeniden ihraç ediliyormuş gibi değerlendirme yapılmaktadır.

\subsubsection{Geri Çekilmiş Sayma Yöntemi (Constructive Retirement Method)}

Geri çekilmiş sayma yönteminin nominal değer yönteminden tek farkı geri alınan payların nominal değerinin, öz kaynakta yeni açılan bir hesap kullanılmak yerine, paylar iptal ediliyormuş gibi doğrudan sermaye hesabından indirilmek suretiyle düşülmesidir. Bu yöntem, şirket yönetiminin geri alınan payları makul bir süre zarfında elden çıkarma niyetinin olmadığı veya geri alınan payların itfasının/iptalinin zorunlu kılındığı durumlara yönelik bir yaklaşım olarak algılanmaktadır (Bragg, 2010: 1006). 


\subsubsection{Yöntemlerin Uygulanması ${ }^{9}$}

Payları borsada işlem gören XYZ A.Ş. yönetim kurulu tarafından şirketin sermayesinin tamamı nakden karş1lanmak üzere 40.000.000 TL'den 240.000.000 TL'ye artırılmasına karar verilmiş; nominal değeri 1 TL olan payların halka arz fiyatı 2 TL olarak tespit edilmiştir. Sermaye artırımı kapsamında pay ihracına ilişkin muhasebe kayıtları aşağıdaki gibidir:

Nakit sermaye artırımı (bin TL)

\begin{tabular}{|l|r|r|l|}
\hline Tekdüzen Hesap Plânı ${ }^{10}$ & \multicolumn{1}{|c|}{ Borç } & Alacak & \multicolumn{1}{l|}{ Hesaplamalar } \\
\hline 102- Bankalar & 400.000 & & $(240.000-40.000) * 2 T L$ \\
\hline 500- Sermaye & & 200.000 & $(240.000-40.000)$ \\
\hline 520- Hisse Senedi İhraç Primleri & & 200.000 & $(2 T L-1 T L) *(240.000-40.000)$ \\
\hline
\end{tabular}

Buna göre, şirket 200.000.000 TL tutarındaki sermaye artırımıyla birlikte piyasadan 400.000.000 TL fon toplamış, aradaki fark kadar ihraç primini öz kaynaklarına yansıtmıştır.

\subsubsection{Payların Geri Alınması}

\subsection{Payların İhraç Bedelinden Yüksek Bir Maliyetle Geri Alımı}

Yönetim kurulu, sermaye artırımı sonrasındaki dönemde dolaşımdaki pay adedi 240.000.000'a ulaşan şirketin paylarının 100.000.000 adedini 2,5 TL'den geri almıştır. Aşağıda şirketin pay geri alım işlemlerini nasıl muhasebeleştirmesi gerektiği görülmektedir:

\section{İhraç bedelinden yüksek bir maliyetle pay geri alımı (bin TL)}

\begin{tabular}{|c|c|c|c|c|c|c|c|}
\hline \multirow[b]{2}{*}{ Tekdüzen Hesap Plânı } & \multirow[b]{2}{*}{ Borç } & \multirow{2}{*}{$\begin{array}{c}\text { Maliyet } \\
\text { Yöntemi } \\
\text { Alacak }\end{array}$} & \multicolumn{2}{|c|}{$\begin{array}{l}\text { Nominal Değer } \\
\text { Yöntemi }\end{array}$} & \multicolumn{2}{|c|}{$\begin{array}{l}\text { Geri Çekilmiş } \\
\text { Sayma Yöntemi }\end{array}$} & \multirow{2}{*}{ Hesaplamalar } \\
\hline & & & Borç & Alacak & Borç & Alacak & \\
\hline 102- Bankalar & & 250.000 & & 250.000 & & 250.000 & $(100.000 .000 * 2,5 T L)$ \\
\hline 500- Sermaye & & & & & 100.000 & & $(100.000 * 1 T L)$ \\
\hline $\begin{array}{l}\text { 504- Geri Alınmış } \\
\text { Hisse Senetleri (-) }\end{array}$ & 250.000 & & 100.000 & & & & $\begin{array}{l}(100.000 .000 * 2,5 T L) v e \\
(100.000 .000 * 1 T L)\end{array}$ \\
\hline $\begin{array}{l}\text { 520- Hisse Senedi İhraç } \\
\text { Primleri }\end{array}$ & & & 100.000 & & 100.000 & & {$[(100.000 .000 *(2 T L-1 T L)]$} \\
\hline $\begin{array}{l}\text { 580- Geçmiş Yıllar } \\
\text { Zararları }\end{array}$ & & & 50.000 & & 50.000 & & $(200.000-250.000)$ \\
\hline
\end{tabular}

\footnotetext{
${ }^{9}$ Uygulamada vergi ve işlem maliyetleri göz ardı edilmiş; geri alınan payların takibinde "ilk giren ilk çıkar" yöntemi benimsenmiştir.

${ }^{10}$ Mevcut tekdüzen hesap plânında bulunmayan hesap kalemlerinin yerine uygun isimli yeni hesap kalemleri eklenmiştir.
} 
Maliyet yönteminde sermaye artırımı esnasında oluşturulan öz kaynak hesap kalemleri muhafaza edilmiş ve geri alınan paylara özgü olarak açılan yeni bir hesaba alış maliyetiyle (250.000.000 TL) kayıt yapılmıştır. Nominal değer yönteminde de söz konusu yeni hesap kullanılmış; ancak, bu defa hesaba geri alınan payların nominal değeri (100.000.000 TL) kaydedilmiştir. Kullanılan diğer hesaplar ise sermaye artırımında oluşturulan ana hesaplardır. Bunun için öncelikle, geri alınan paylara ait ilk ihraçta kaydedilmiş bulunan ihraç primleri hesabının borçlandırılması; alış bedelinin (250.000.000 TL) sermaye artırımında geri alınan paylara tekabül eden toplam ihraç bedelinden [100.000.000 TL (nominal değer) + 100.000.000 $\mathrm{TL}^{11}$ (geri alınan paylara tekabül eden ihraç primi) = 200.000.000 TL] fazla olması nedeniyle de, aradaki fark için ayrıca ilâveten geçmiş yıl zararı kaydı yapılması gerekmektedir. Geri çekilmiş sayma yönteminde ise, nominal değer yönteminden farklı olarak geri alınan payların nominal değeri sermaye hesabından indirilmiştir. Bu işlemlerle birlikte dolaşımdaki pay sayısı 140.000.000 (240.000.000-100.000.000) adede düşmüştür. Şirket nezdinde ise 100.000 .000 adet pay bulunmaktadir.

\subsection{Payların İhraç Bedelinden Düşük, Nominal Değerinden Yüksek Bir Maliyetle Geri Alımı}

Aradan geçen süre zarfında şirket paylarının piyasadaki gidişatından memnun olmayan yönetim, pay fiyatının desteklenebilmesi amacıyla şirketin paylarının 10.000.000 adedini 1,5 TL'den geri almıştır. İşleme ilişkin muhasebe kayıtları aşağıdaki gibidir:

\section{İhraç bedelinden düşük, nominal değerinden yüksek bir maliyetle pay geri alımı} (bin TL)

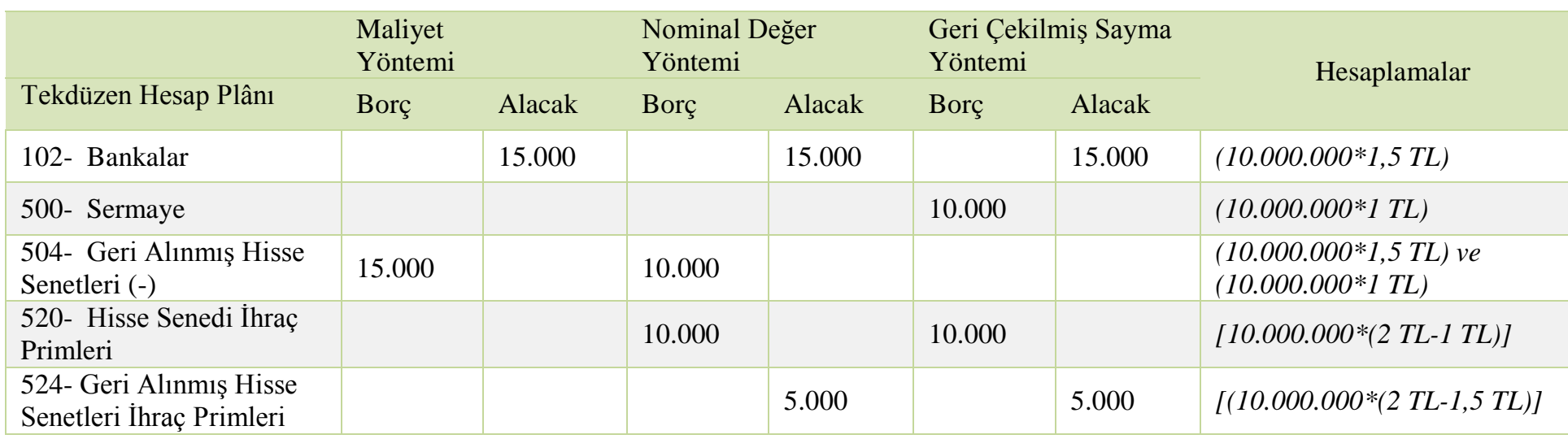

Görüldüğü gibi, payların ihraç bedelinden daha düşük bir fiyattan geri alınması hâlinde maliyet yönteminin işleyişinde herhangi bir farklılık bulunmamakta; ancak, nominal

\footnotetext{
${ }^{11} \mathrm{Bu}$ tutar halka arz fiyatı (2 TL) ile nominal değer (1 TL) arasındaki farkın (1 TL) geri alınan payların nominal değeriyle (100.000.000 TL) çarpımı sonucunda elde edilmektedir.
} 
değer ve geri çekilmiş sayma yöntemlerinde, bir önceki muhasebe kaydı örneğinde geçmiş yıl zararıyla ilişkilendirilen farkı temsil eden 5.000.000 TL, bu defa, maliyet yönteminde de kullanılan, geri alınan paylara özgü bir pay ihraç primi hesabına alacak olarak kaydedilmektedir. Mevcut durumda, dolaşımdaki pay sayıs1 130.000.000 (140.000.00010.000.000); şirket nezdindeki pay sayısı ise $110.000 .000(100.000 .000+10.000 .000)$ adettir.

\subsection{Payların Nominal Bedelinden Düşük Bir Maliyetle Geri Alımı}

Paylardaki şiddetli düşüşün devam ettiğini gören yönetim geri alım işlemlerine devam etme niyetindedir. Bu kapsamda, dolaşımdaki payların yine 10.000.000 adedi 0,5 TL'den geri alınmıştır.

Nominal bedelinden düşük bir maliyetle pay geri alımı (bin TL)

\begin{tabular}{|c|c|c|c|c|c|c|c|}
\hline \multirow[b]{2}{*}{ Tekdüzen Hesap Plânı } & \multicolumn{2}{|c|}{$\begin{array}{l}\text { Maliyet } \\
\text { Yöntemi }\end{array}$} & \multicolumn{2}{|c|}{$\begin{array}{l}\text { Nominal Değer } \\
\text { Yöntemi }\end{array}$} & \multicolumn{2}{|c|}{$\begin{array}{l}\text { Geri Çekilmiş Sayma } \\
\text { Yöntemi }\end{array}$} & \multirow{2}{*}{ Hesaplamalar } \\
\hline & Borç & Alacak & Borç & Alacak & Borç & Alacak & \\
\hline 500- Sermaye & & & & & 10.000 & & $(10.000 .000 * 1 \mathrm{TL})$ \\
\hline $\begin{array}{l}\text { 504- Geri Alınmış Hisse } \\
\text { Senetleri (-) }\end{array}$ & 5.000 & & 10.000 & & & & $\begin{array}{l}(10.000 .000 * 0,5 T L) v e \\
(10.000 .000 * 1 \mathrm{TL})\end{array}$ \\
\hline $\begin{array}{l}\text { 524- Geri Alınmış Hisse } \\
\text { Senetleri İhraç Primleri }\end{array}$ & & & & 15.000 & & 15.000 & {$[(10.000 .000 *(2 T L-0,5 T L)]$} \\
\hline
\end{tabular}

Payların nominal veya ihraç bedelinden düşük bir fiyattan geri alınması yukarıdaki kayıtlardan da anlaşılabileceği gibi muhasebe kayıtlarına aynı şekilde etki etmektedir. Dikkat çekici olan husus, bir önceki örnekte geri alınan paylara ilişkin olanlar da dâhil olmak üzere hisse senedi ihraç primleri hesabının nette 5.000 TL (10.000 TL-5.000 TL) eksilmesine karşılık, bu örnekte aynı tutarda (15.000 TL-10.000 TL) artmasıdır. Bir başka deyişle, yapılan geri alım işlemleri sonucunda ilk ihraca ilişkin prim hesabında gerekli düzeltmeler yapılmaktadır. Son durum itibarıla dolaşımdaki pay sayısı 120.000 .000 (130.000.00010.000.000) adede gerilemiş; şirket nezdindeki pay sayıs1 ise 120.000 .000 $(110.000 .000+10.000 .000)$ adede yükselmiştir.

\subsubsection{Geri Alınan Payların Elden Çıkarılması ${ }^{12}$}

\subsection{Payların Geri Alım Bedelinden Yüksek Bir Bedelle Elden Çıkarılması}

Şirket geri alınan paylarının altıda birini (20.000.000 adet) 3 TL'den elden çıkarmıştır. Söz konusu işleme ilişkin muhasebe kayıtlarına aşağıda yer verilmektedir:

\footnotetext{
${ }^{12}$ Bu bölümdeki örneklerde, ilk giren ilk çıkar yöntemi benimsendiğinden, 2,5 TL üzerinden geri alınmış bulunan payların elden çıkarıldığı varsayılmıştır.
} 
Payların geri alım bedelinden yüksek bir bedelle elden çıkarılması (bin TL)

\begin{tabular}{|c|c|c|c|c|c|c|c|}
\hline \multirow[b]{2}{*}{ Tekdüzen Hesap Plânı } & \multirow[b]{2}{*}{ Borç } & \multirow{2}{*}{$\begin{array}{l}\text { Maliyet } \\
\text { Yöntemi } \\
\text { Alacak }\end{array}$} & \multicolumn{2}{|c|}{$\begin{array}{l}\text { Nominal Değer } \\
\text { Yöntemi }\end{array}$} & \multicolumn{2}{|c|}{$\begin{array}{l}\text { Geri Çekilmiş Sayma } \\
\text { Yöntemi }\end{array}$} & \multirow{2}{*}{ Hesaplamalar } \\
\hline & & & Borç & Alacak & Borç & Alacak & \\
\hline 500- Sermaye & & & & & & 20.000 & $(20.000 .000 * 1 \mathrm{TL})$ \\
\hline $\begin{array}{l}\text { 504- Geri Alınmış } \\
\text { Hisse Senetleri (-) }\end{array}$ & & 50.000 & & 20.000 & & & $\begin{array}{l}(20.000 .000 * 2,5 T L) v e \\
(20.000 .000 * 1 T L)\end{array}$ \\
\hline $\begin{array}{l}\text { 524- Geri Alınmış } \\
\text { Hisse Senetleri İhraç } \\
\text { Primleri }\end{array}$ & & 10.000 & & & & & {$[(20.000 .000 *(3 T L-2,5 T L)]$} \\
\hline
\end{tabular}

Maliyet ve nominal değer yönteminde açılmış bulunan geri alınan paylara ilişkin hesabın; geri çekilmiş sayma yönteminde ${ }^{13}$ ise, sermaye hesabının altıda bir tutarında ters kayıtla kapatılması sonucunda, dolaşımdaki pay sayısının 140.000 .000 $(120.000 .000+20.000 .000)$; şirket nezdindeki pay sayısının ise $100.000 .000(120.000 .000-$ 20.000.000) adede ulaştı̆̆ anlaşılabilmektedir. Geri alınan payların 20.000.000 adede tekabül eden altıda birinin satış bedelinin (60.000.000 TL) geri alım bedelinden (50.000.000 TL) yüksek olması nedeniyle, maliyet yönteminde aradaki fark (10.000.000 TL) ilk ihraçta ihraç primi kaydı yapılırmış gibi, geri alınan paylara özgü bir pay ihraç primi hesabına kaydedilmektedir. $\mathrm{Bu}$ şekilde, payların ilk ihracında açılmış bulunan hesaplar muhafaza edilmiş; daha da önemlisi, satışa konu edilen geri alınmış paylara ilişkin bilginin ilk ihraç edilen paylara ilişkin bilgiden ayrıştırılarak kolayca takip edilebilmesi sağlanmış olmaktadır. Diğer taraftan, nominal değer yönteminde, geri alınan payların nominal değerinde gerekli düzeltme yapıldıktan sonra satış bedeli (60.000.000 TL) ile nominal değer (20.000.000 TL) arasındaki fark (40.000.000 TL) yeni bir pay ihracından ziyade aynı paylar yeniden ihraç ediliyormuş gibi muamele görmekte ve ilk ihraç işleminde olduğu gibi pay ihraç primi hesabına kaydedilmektedir. Geri çekilmiş sayma yönteminde ise, geri alınan paylarla ilgili düzeltme işlemi nominal değer yönteminden farklı olarak sermaye hesabında yapılmaktadır.

\subsection{Payların Geri Alım Bedelinden Düşük, İhraç Bedelinden Yüksek Bir Bedelle EIden Çıkarılması}

Şirket tarafından geri alınmış payların beşte biri (20.000.000 adet) daha, ancak bu defa 2,3 TL'den satılmıştır.

\footnotetext{
${ }^{13}$ Geri alınan payların satışının söz konusu olduğu durumlarda esasen şirket tarafından geri çekilmiş sayma yönteminin uygulanmış olması yöntemin amacıyla çelişmekle birlikte, yönteme bu örnekte diğer yöntemlerle karşılaştırılabilmesi amacıyla yer verilmesinde fayda görülmüştür.
} 


\section{Payların, geri alım bedelinden düşük, ihraç bedelinden yüksek bir bedelle elden çıkarılması (bin TL)}

\begin{tabular}{|c|c|c|c|c|c|c|c|}
\hline \multirow[b]{2}{*}{ Tekdüzen Hesap Plânı } & \multicolumn{2}{|c|}{$\begin{array}{l}\text { Maliyet } \\
\text { Yöntemi }\end{array}$} & \multicolumn{2}{|c|}{$\begin{array}{l}\text { Nominal Değer } \\
\text { Yöntemi }\end{array}$} & \multicolumn{2}{|c|}{$\begin{array}{l}\text { Geri Çekilmiş Sayma } \\
\text { Yöntemi }\end{array}$} & \multirow{2}{*}{ Hesaplamalar } \\
\hline & Borç & Alacak & Borç & Alacak & Borç & Alacak & \\
\hline 102- Bankalar & 46.000 & & 46.000 & & 46.000 & & $(20.000 .000 * 2,3 T L)$ \\
\hline 500- Sermaye & & & & & & 20.000 & $(20.000 .000 * 1 T L)$ \\
\hline $\begin{array}{l}\text { 504- Geri Alınmış Hisse } \\
\text { Senetleri (-) }\end{array}$ & & 50.000 & & 20.000 & & & $\begin{array}{l}(20.000 .000 * 2,5 T L) v e \\
(20.000 .000 * 1 T L)\end{array}$ \\
\hline $\begin{array}{l}\text { 520- Hisse Senedi İhraç } \\
\text { Primleri }\end{array}$ & & & & 26.000 & & 26.000 & {$[20.000 .000 *(2,3 T L-1 T L)]$} \\
\hline $\begin{array}{l}\text { 524- Geri Alınmış Hisse } \\
\text { Senetleri İhraç Primleri }\end{array}$ & 4.000 & & & & & & {$[(20.000 .000 *(2,3 T L-2,5 T L)]$} \\
\hline
\end{tabular}

Payların geri alım bedelinden düşük bir fiyatla elden çıkarılması sonucunda maliyet yönteminde, 20.000 .000 adet paya ait satı̧ bedeli $(46.000 .000 \mathrm{TL})$ ile geri alım bedeli (50.000.000 TL) arasındaki fark (4.000.000 TL) daha önce oluşturulmuş bulunan geri alınan paylara özgü pay ihraç primi hesabından düşülmektedir. Nominal değer yönteminde ise, geri alınan payların ilk ihraç bedelinin üzerindeki bir fiyatla satışına bağlı olarak söz konusu 20.000.000 adet paya ait ilk ihraç bedeli (40.000.000 TL) ile satış bedeli (46.000.000 TL) arasındaki fark (6.000.000 TL) kadar ilave ihraç primi yaratılabilmektedir. Dolaşımdaki pay sayıs1, mevcut durumda 160.000.000 (140.000.000+20.000.000) adede ulaşmış; şirket nezdindeki pay sayısı ise 80.000.000 (100.000.000-20.000.000) adede gerilemiştir.

\subsection{Payların İhraç Bedelinden Düşük, Nominal Değerinden Yüksek Bir Bedelle Eıden Çıkarılması}

Piyasadaki dalgalanmaya istinaden şirket paylarının fiyatında düşüşler gözlemlenmiş ve geri alınmış payların 1/4'ü (20.000.000 adet), 1,5 TL'den satılmıştır.

Payların, ihraç bedelinden düşük, nominal değerinden yüksek bir bedelle elden çıkarılması (bin TL)

\begin{tabular}{|c|c|c|c|c|c|c|c|}
\hline \multirow[b]{2}{*}{ Tekdüzen Hesap Plânı } & \multicolumn{2}{|c|}{ Maliyet Yöntemi } & \multicolumn{2}{|c|}{$\begin{array}{l}\text { Nominal Değer } \\
\text { Yöntemi }\end{array}$} & \multicolumn{2}{|c|}{$\begin{array}{l}\text { Geri Çekilmiş Sayma } \\
\text { Yöntemi }\end{array}$} & \multirow{2}{*}{ Hesaplamalar } \\
\hline & Borç & Alacak & Borç & Alacak & Borç & Alacak & \\
\hline 102- Bankalar & 30.000 & & 30.000 & & 30.000 & & $(20.000 .000 * 1,5 T L)$ \\
\hline 500- Sermaye & & & & & & 20.000 & $(20.000 .000 * 1 T L)$ \\
\hline $\begin{array}{l}\text { 504- Geri Alınmış Hisse } \\
\text { Senetleri (-) }\end{array}$ & & 50.000 & & 20.000 & & & $\begin{array}{l}(20.000 .000 * 2,5 T L) v e \\
(20.000 .000 * 1 T L)\end{array}$ \\
\hline $\begin{array}{l}\text { 520- Hisse Senedi İhraç } \\
\text { Primleri }\end{array}$ & & & & 10.000 & & 10.000 & {$[20.000 .000 *(1,5 T L-1 T L)]$} \\
\hline $\begin{array}{l}\text { 524- Geri Alınmış Hisse } \\
\text { Senetleri İhraç Primleri }\end{array}$ & 6.000 & & & & & & \multirow{2}{*}{$(20.000 .000 *(1,5 T L-2,5 T L)]$} \\
\hline $\begin{array}{l}\text { 580- Geçmiş Yıllar } \\
\text { Zararları }\end{array}$ & 14.000 & & & & & & \\
\hline
\end{tabular}


Geri alınan payların ihraç bedelinden düşük bir fiyatla elden çıkarılmasının maliyet yönteminde geçmiş yıl zararını artırmasına neden olduğu gözlenmektedir. $\mathrm{Bu}$ etkinin (14.000.000 TL) oluşmasının sebebi geri alım işlemlerinin ilk ihraçta oluşturulan ana hesaplarla ilişkilendirilmemesidir. Bir başka deyişle, şirketi zarara uğratabilecek satışların mevcut öz kaynak fonlarıyla karşılanabilme imkânı bulunmamaktadır. Bu yöntemde, daha önce oluşturulmuş bulunan geri alınan paylara özgü pay ihraç primi hesabındaki bakiye tutar kullanıldıktan sonra aşan kısım geçmiş yıllar zararı olarak değerlendirilmektedir. Buna göre, öz kaynaklarda 20.000.000 TL tutarında meydana gelen azalışın 6.000.000 TL'lik kısmı geri alınan paylara özgü pay ihraç primi hesabından kullanılmakta, kalan tutar da geçmiş yıllar zararına kayıtlanmaktadır. Dolaşımdaki pay sayısı 180.000.000 (160.000.000+20.000.000); şirket nezdindeki pay sayısı ise 60.000 .000 (80.000.000-20.000.000) adettir.

\subsection{Payların Nominal Değerinden Düşük Bir Bedelle Elden Çıkarılması}

Piyasalarda yaşanan aşağı yönlü hareketin had safhaya ulaştığı bu dönemde şirketinkiler de dâhil olmak üzere birçok pay nominal değerinin altında işlem görmeye başlamıştır. Şirket geri alınmış bakiye payların 1/3'ünü (20.000.000 adet) 0,5 TL'den satmıştır.

\section{Payların, nominal değerinden düşük bir bedelle elden çıkarılması (bin TL)}

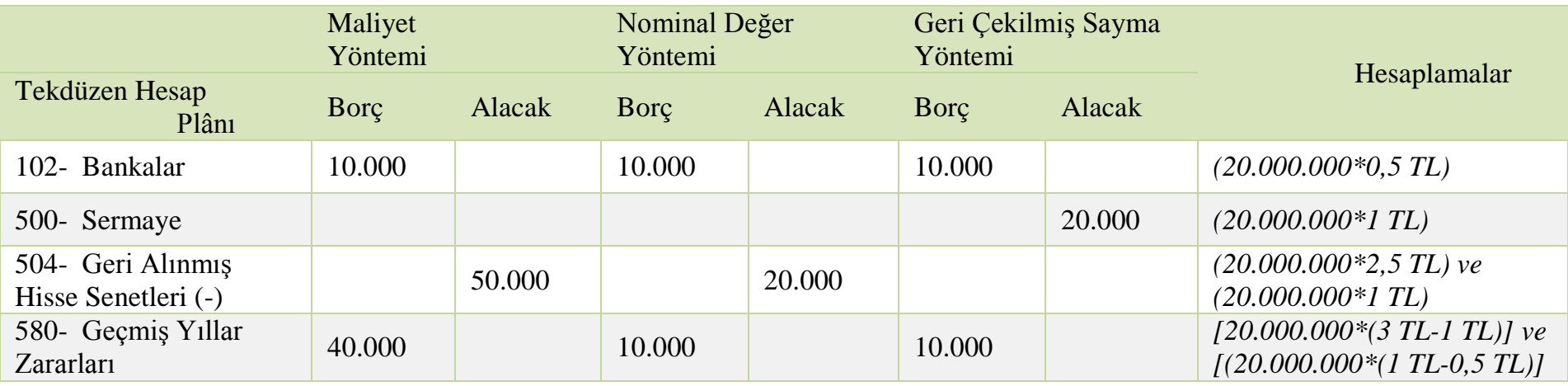

$\mathrm{Bu}$ işlemle birlikte geri alınan payların nominal değerinin altında elden çıkarılması sonucunda her üç yöntemde de geçmiş yıl zararı oluştuğu anlaşılmaktadır. Nominal değer ve geri çekilmiş sayma yöntemlerinde, nominal değerin altında bir satış yapılmasına istinaden artık ihraç primi yazılma imkânı kalmadığından geçmiş yıllar zararı hesabını kullanma gereği ortaya çıkmıştır. $\mathrm{Bu}$ işlem sonucunda dolaşımdaki pay sayısı 200.000.000 $(180.000 .000+20.000 .000)$ adede ulaşmış; şirket nezdindeki pay sayıs ise 40.000 .000 (60.000.000-20.000.000) adede gerilemiştir. 


\subsubsection{Geri Alınan Payların İtfa Edilmesi ${ }^{14}$}

Şirket, nezdinde bulunan paylarının yarısını (20.000.000 adet) itfa etmeye karar vermiş̧tir. Aşağıdaki muhasebe kayıtları üç yöntem itibarıyla itfa işleminin etkilerini göstermektedir:

\section{Payların itfa edilmesi (bin TL)}

\begin{tabular}{|c|c|c|c|c|c|c|c|}
\hline \multirow[b]{2}{*}{ Tekdüzen Hesap Plânı } & \multicolumn{2}{|c|}{$\begin{array}{l}\text { Maliyet } \\
\text { Yöntemi }\end{array}$} & \multicolumn{2}{|c|}{$\begin{array}{l}\text { Nominal Değer } \\
\text { Yöntemi }\end{array}$} & \multicolumn{2}{|c|}{$\begin{array}{l}\text { Geri Çekilmiş } \\
\text { Sayma Yöntemi }\end{array}$} & \multirow{2}{*}{ Hesaplamalar } \\
\hline & Borç & Alacak & Borç & Alacak & Borç & Alacak & \\
\hline 500- Sermaye & 20.000 & & 20.000 & & & & $(20.000 .000 * 1 T L)$ \\
\hline $\begin{array}{l}\text { 504- Geri Alınmış } \\
\text { Hisse Senetleri (-) }\end{array}$ & & 50.000 & & 20.000 & & & $\begin{array}{l}(20.000 .000 * 2,5 T L) \text { ve } \\
(20.000 .000 * 1 T L)\end{array}$ \\
\hline $\begin{array}{l}\text { 520- Hisse Senedi } \\
\text { İhraç Primleri }\end{array}$ & 20.000 & & & & & & {$[20.000 .000 *(2 T L-1 T L)]$} \\
\hline $\begin{array}{l}\text { 580- Geçmiş Yıllar } \\
\text { Zararları }\end{array}$ & 10.000 & & & & & & {$[20.000 .000 *(2 T L-2,5 T L)]$} \\
\hline
\end{tabular}

Yapılan işlemler sonucunda maliyet ve nominal değer yöntemlerinde sermaye hesabı düzeltilmiş; ancak, geri çekilmiş sayma yönteminde zaten payların baştan itfa edildiği varsayıldığı için ilâve bir düzeltme yapılmasına gerek kalmamıştır. Ayrıca, maliyet yönteminde, itfa söz konusu olduğundan ilk defa bu aşamada ilk ihraçta oluşturulan ana hesaplara kayıt yapılmıştır. Buna göre, 20.000.000 adede tekabül eden aynı tutardaki pay ihraç primi itfaya istinaden hesaptan düşülmüş, kalan fark ise geçmiş yıllar zararına kaydedilmiştir.

\subsubsection{Yöntemlerin Kıyaslanması}

Geri alım işlemleri finansal tablolara temel olarak öz kaynaklardaki değiş̧im anlamında etki etmektedir. Bu nedenle, yukarıda yer verilen geri alım, elden çıkarma ve itfa işlemlerinin tek bir tabloda birikimli olarak gösterilmesinin öz kaynaktaki toplam etkinin değerlendirilmesine daha fazla imkân tanıyacağı düşünülmektedir:

Öz kaynak hesaplarında gerçekleşen değişiklikler

\begin{tabular}{|c|c|c|c|c|}
\hline & & $\begin{array}{l}\text { Maliyet } \\
\text { Yöntemi }\end{array}$ & $\begin{array}{l}\text { Nominal Değer } \\
\text { Yöntemi }\end{array}$ & $\begin{array}{l}\text { Geri Çekilmiş } \\
\text { Sayma Yöntemi }\end{array}$ \\
\hline SPK Format ${ }^{15}$ & Tekdüzen HesapPlânı & (bin TL) bölüm no & (bin $T L)$ bölüm no & (bin TL) bölüm no \\
\hline Ödenmiş Sermaye & 500- Sermaye & $-20.000^{(2.1 .2 .3 .)}$ & $-20.000^{(2.1 .2 .3 .)}$ & $\begin{array}{r}-100.000^{(2.1 .2 .1 .1 .)} \\
-10.000^{(3.1 .1 .2 .)} \\
-10.000^{(2.1 .2 .1 .3 .)}\end{array}$ \\
\hline
\end{tabular}

\footnotetext{
${ }^{14}$ Bu bölümdeki örnekte, ilk giren ilk çıkar yöntemi benimsendiğinden, 2,5 TL üzerinden geri alınmış bulunan payların itfa edildiği varsayılmıştır.

15 2013/19 sayılı SPK Bülteni ile ilân edilmiştir. Bu formatlar uyarınca geri alınan paylara ilişkin alım bedellerinin öz kaynaktan düşülerek "Geri Alınmış Paylar (-)" kaleminde gösterilmesi gerekmektedir. Buna göre, SPK tarafından geri alınan payların muhasebeleştirilmesinde maliyet yönteminin tercih edildiği anlaşılmaktadır.
} 


\begin{tabular}{|c|c|c|c|c|}
\hline & & & & $\begin{array}{l}+20.000^{(2.1 .2 .2 .1 .)} \\
+20.000^{(2.1 .2 .2 .2 .)} \\
+20.000^{(2.1 .2 .2 .3 .)} \\
+20.000^{(2.1 .2 .2 .4 .)}\end{array}$ \\
\hline $\begin{array}{l}\text { Geri Alınmış } \\
\text { Paylar (-) }\end{array}$ & $\begin{array}{l}\text { 504- Geri Alınmış } \\
\text { Hisse Senetleri (-) }\end{array}$ & $\begin{array}{r}-250.000^{(2.1 .2 .1 .1 .)} \\
-15.000^{(2.1 .2 .1 .2 .)} \\
-5.000^{(2.1 .2 .1 .3 .)} \\
+50.000^{(2.1 .2 .2 .1 .)} \\
+50.000^{(2.1 .2 .2 .2 .)} \\
+50.000^{(2.1 .2 .2 .3 .)} \\
+50.000^{(2.1 .2 .2 .4 .)} \\
+50.000^{(2.1 .2 .3)}\end{array}$ & $\begin{array}{r}-100.000^{(2.1 .2 .1 .1 .)} \\
-10.000^{(2.1 .2 .1 .2 .)} \\
-10.000^{(2.1 .2 .1 .3 .)} \\
+20.000^{(2.1 .2 .2 .1 .)} \\
+20.000^{(2.1 .2 .2 .2 .)} \\
+20.000^{(2.1 .2 .2 .3 .)} \\
+20.000^{(2.1 .2 .2 .4 .)} \\
+20.000^{(2.1 .2 .3)}\end{array}$ & \\
\hline $\begin{array}{l}\text { Paylara İlişkin } \\
\text { Primler/İskontolar }\end{array}$ & $\begin{array}{l}\text { 520- Hisse Senedi } \\
\text { İhraç Primleri }\end{array}$ & $-20.000^{(2.1 .2 .3)}$ & $\begin{array}{r}-100.000^{(2.1 .2 .1 .1 .)} \\
-10.000^{(2.1 .2 .1 .2 .)} \\
-10.000^{(2.1 .2 .1 .3 .)} \\
+40.000^{(2.1 .2 .2 .1 .)} \\
+26.000^{(2.1 .2 .2 .2 .)} \\
+10.000^{(2.1 .2 .2 .3 .)}\end{array}$ & $\begin{array}{r}-100.000^{(2.1 .2 .1 .1 .)} \\
-10.000^{(2.1 .2 .1 .2 .)} \\
-10.000^{(2.1 .2 .1 .3 .)} \\
+40.000^{(2.1 .2 .2 .1 .)} \\
+26.000^{(2.1 .2 .2 .2 .)} \\
+10.000^{(2.1 .2 .2 .3 .)}\end{array}$ \\
\hline $\begin{array}{l}\text { Geçmiş Yıllar } \\
\text { Karları/Zararları }\end{array}$ & $\begin{array}{l}\text { 580- Geçmiş Yıllar } \\
\text { Zararları }\end{array}$ & $\begin{array}{r}-14.000^{(2.1 .2 .2 .3 .)} \\
-40.000^{(2.1 .2 .2 .4 .)} \\
-10.000^{(2.1 .2 .3)}\end{array}$ & $\begin{array}{l}-50.000^{(2.1 .2 .1 .1 .)} \\
-10.000^{(2.1 .2 .2 .4 .)}\end{array}$ & $\begin{array}{l}-50.000^{(2.1 .2 .1 .1 .)} \\
-10.000^{(2.1 .2 .2 .4 .)}\end{array}$ \\
\hline $\begin{array}{l}\text { Geri Alınan } \\
\text { Paylara İlişkin } \\
\text { Primler/İskontolar }\end{array}$ & $\begin{array}{l}\text { 524- Geri Alınmış } \\
\text { Hisse Senetleri İhraç } \\
\text { Primleri }\end{array}$ & $\begin{array}{r}+10.000^{(2.1 .2 .2 .1 .)} \\
-4.000^{(2.1 .2 .2 .2 .)} \\
-6.000^{(2.1 .2 .2 .3 .)}\end{array}$ & $\begin{array}{r}+5.000^{(2.1 .2 .1 .2 .)} \\
+15.000^{(2.1 .2 .1 .3 .)}\end{array}$ & $\begin{array}{l}+5.000^{(2.1 .2 .1 .2 .)} \\
+15.000^{(2.1 .2 .1 .3 .)}\end{array}$ \\
\hline \multicolumn{2}{|c|}{ Öz Kaynaktaki Toplam Etki } & -124.000 & -124.000 & -124.000 \\
\hline
\end{tabular}

Yukarıdaki tablodan, hangi yöntem kullanılırsa kullanılsın öz kaynakta yaratılan birikimli etki bakımından herhangi bir farklılık oluşmadığı; üç yöntemi birbirinden yalnızca işleme bakış açıları ve kullanılan hesap kalemlerinin ayırdığı görülmektedir.

Buna göre, maliyet yönteminde, geri alınan payların itfa edilmeyeceği varsayımından hareketle, paylara ait ana öz kaynak hesaplarına dokunulmayıp geri alınan paylara özgü geçici nitelikteki hesaplarla muhasebeleştirme yapılması esastır. Nominal değer ve geri çekilmiş sayma yöntemlerinde ise, payların itfa edileceği varsayımından hareketle, paylara ait ana öz kaynak hesapları kullanılarak muhasebeleştirme yapılmakta, nominal değer yönteminde farklı olarak geri alınan paylara ilişkin hesap kaleminin ana hesaplardan ayrıştırılması sağlanmaktadır. $\mathrm{Bu}$ nedenle, nominal değer ve geri çekilmiş sayma yöntemleri anlayış bakımından benzerlik göstermektedir. Maliyet yönteminde benimsenen bakış açısının farklılığı ise, payların itfa edilmesinin söz konusu olması hâlinde örneğin nominal değer yönteminde yapılması gereken tek işlem sermaye hesabının geri alınan paylarla kapatılmasıyken; maliyet yönteminde, geri alınan paylara ilişkin ana kayıtların ilk defa kullanılmasından kaynaklanan düzeltme işleminde kendini belli etmektedir.

\subsection{Pay Geri Alım İșlemlerinin Raporlanmasında Diğer İșlemler}

TMS/TFRS'de pay geri alımlarıyla ilgili diğer işlemler TFRS 2 - "Hisse Bazlı Ödemeler” (IFRS 2 - "Share-based Payment”), TMS 7 - "Nakit Akış Tabloları" (IAS 7 "Statement of Cash Flows”), TMS 24 - “İlişkili Taraf Açıklamaları” (IAS 24 - "Related Party 
Disclosures”) ve TMS 33 - "Hisse Başına Kazanç" (IAS 33 - "Earnings Per Share”) standartlarında düzenlenmektedir. Ayrıca, pay geri alım işlemleri şirketin bağlı ortaklıkları tarafından da gerçekleştirilebilmektedir. Bu durumda bağlı ortaklık tarafından geri alınan paylar şirket tarafından geri alınmış kabul edilmektedir. Ancak, geri alım işlemlerinin finansal tablolara olan etkilerinin konsolide finansal tablolar açısından farklı boyutları olabilmektedir. Bu nedenle, TFRS 10 - "Konsolide Finansal Tablolar” (IFRS 10 - “Consolidated Financial Statements") standardının da dikkate alınması gerekmektedir.

\subsubsection{Geri Alınan Payların Pay Bazlı Ödemelerde Kullanılması}

Çalışanlara pay veya pay opsiyonları şeklinde yapılan ödemeler günümüzde, çalışanların şirkete olan bağlılıklarının artırılmasında önemli bir rol oynamaktadır. İşlemlerin giderek artan önemi, IAS/IFRS'in bu konunun başlı başına ayrı bir standartta incelenmesini gerektirmiş ve 2004 yılında yayımlanan IFRS 2 - "Share-based Payment" standardıyla bu alandaki boşluk giderilmiştir. Buna göre, şirketlerin; çalışanlarından, kendilerine pay olarak yapılan ödemeler karşılığında hizmet aldığı veya çalışanlarından aldığı hizmetler karşılığında şirket paylarının değeri üzerinden nakit ödeme yapma yükümlülüğüne girdiği işlemleri ${ }^{16}$ bu standart uyarınca muhasebeleştirmesi gerekmektedir. Pay geri alımları ise söz konusu işlemlerden ilki kapsamında değerlendirilmektedir. Çalışanlarına pay opsiyonu yazmış bir şirketin, opsiyon kullanımının söz konusu olduğu bir durumda, yeni pay ihraç etmek yerine paylarını piyasadan geri alarak çalışanlarına ödemesi bu işlemlere bir örnek olarak verilebilir.

Diğer taraftan, geri alınan payların muhasebeleştirilmesinde benimsenen öz kaynaktan indirme yöntemi, çalışanlara payla yapılan ödemelerde belli koşulların ortaya çıkması hâlinde de kullanılmaktadır. Ayrıca, ödeme plânları kapsamında çalışanlara ödenen payların şirket tarafından geri alınması da söz konusu olabilmekte; bu durumda, geri alım için ödenen bedeller gider olarak kayıtlanmayıp öz kaynakla ilişkilendirilmektedir (TFRS/IFRS 2: Para. 29).

\section{Örnek muhasebe uygulaması: Çalışanlara yapılan ödemeler ve geri alınan paylar} (bin TL)

XYZ A.Ş.'de 2010 yılının başında bir yöneticiye, 3 senelik hizmetini tamamlaması şartıyla pay başına 33 TL'den 10.000 adet pay ödemesi yapılmasına karar verilmiştir.

TFRS/IFRS 2 uyarınca, çalışanlardan alınan hizmetlerin, payların gerçeğe uygun değeri dikkate alınarak, pay bazlı ödemenin yapılmasına karar verildiği tarih itibarıyla ölçülmesi ve ölçümlenen bu tutarın hak ediş dönemi boyunca gider olarak kayıtlanarak asgarî tutarı teşkil etmesi gerekmektedir (TFRS/IFRS 2: Para. 27).

\footnotetext{
16 Standartta her iki işlem de pay bazlı ödeme olarak sınıflandırılmaktadır. Ancak, çalışanlardan alınan hizmetlerin karşılığının işlemlerin ilkinde pay olarak aynen (equity-settled share-based payments); ikincisinde ise payların gerçeğe uygun değeri dikkate alınarak nakden (cash-settled share-based payments) ödenmesi söz konusudur (TFRS/IFRS 2: Ek/Appendix A).
} 


\begin{tabular}{|c|c|c|c|c|}
\hline Y1l & SPK Format 1 & Tekdüzen Hesap Plânı & Borç & Alacak \\
\hline \multirow{2}{*}{2010} & Genel Yönetim Giderleri & $\begin{array}{l}\text { 632- Genel Yönetim } \\
\text { Giderleri }\end{array}$ & 110.000 & \\
\hline & Geçmiş Yıllar Kârları/Zararları & $\begin{array}{l}\text { 570- Geçmiş Yıllar } \\
\text { Karları }\end{array}$ & & 110.000 \\
\hline
\end{tabular}

Pay bazlı ödemenin yapılmasına karar verildiği tarihi itibarıyla, 3 yıl sürecek hak ediş döneminin sonunda yapılması plânlanan toplam 330.000 TL (33 $T L * 10.000)$ ödemenin birinci yıla tekabül eden kısmı 110.000 TL (330.000 TL*1/3) olarak hesaplanmıştır. Gider olarak kayıtlanan bu tutar aynı zamanda bir öz kaynak hesabıyla ilişkilendirilmiştir ${ }^{17}$.

$\mathrm{Bu}$ dönemde yaşanan birtakım gelişmeler sonucunda çalışanlara nakit ödeme yapılması gereği doğarsa aşağıdaki kaydın yapılması gerekecektir:

\begin{tabular}{|c|c|c|c|c|}
\hline Y1l & SPK Formatı & $\begin{array}{l}\text { Tekdüzen Hesap } \\
\text { Plânı }\end{array}$ & Borç & Alacak \\
\hline \multirow{3}{*}{2010} & Geçmiş Yıllar Kârları/Zararları & $\begin{array}{l}\text { 580- Geçmiş Yıllar } \\
\text { Zararları }\end{array}$ & 110.000 & \\
\hline & Genel Yönetim Giderleri & $\begin{array}{l}\text { 632- Genel Yönetim } \\
\text { Giderleri }\end{array}$ & 220.000 & \\
\hline & Nakit ve Nakit Benzerleri & 102- Bankalar & & 330.000 \\
\hline
\end{tabular}

Buna göre, pay olarak ödenmesi kararlaştırılan bir plânda süreç içinde nakdî ödeme yapılması şeklinde bir değişiklik yapılırsa işlem geri alımların muhasebeleştirilmesinde olduğu gibi öz kaynaktan indirilerek kayıtlara yansıtılmaktadır. Bu indirim ancak yükümlülüğün geri alınan payların değerini aşmadığı tutar kadar yapılabilmekte; aşan tutar gider olarak kayıtlanmaktadır (TFRS/IFRS 2: Para. 28).

Bununla birlikte, böyle bir durum yaşanmamış ve plâna aynen devam edilmiştir.

2011 yılının sonunda şirketin pay fiyatı 25 TL’ye düşmüştür. Bunun üzerine ödeme plânına hak ediş döneminin sonunda 10.000 adet pay yerine bu payların değerine tekabül eden tutarda nakit ödeme seçeneği de getirilerek yöneticinin tercihine bırakılmıştır.

\begin{tabular}{|c|c|c|c|c|}
\hline Y1l & SPK Formatı & Tekdüzen Hesap Plânı & Borç & Alacak \\
\hline \multirow{4}{*}{011} & Genel Yönetim Giderleri & $\begin{array}{l}\text { 632- Genel Yönetim } \\
\text { Giderleri }\end{array}$ & \multirow[t]{2}{*}{110.000} & \\
\hline & Geçmiş Yıllar Kârları/Zararları & $\begin{array}{l}\text { 570- Geçmiş Yıllar } \\
\text { Karları }\end{array}$ & & 110.000 \\
\hline & Geçmiş Yıllar Kârları/Zararları & $\begin{array}{l}\text { 580- Geçmiş Yıllar } \\
\text { Zararları }\end{array}$ & 166.667 & \\
\hline & $\begin{array}{l}\text { Çalışanlara Sağlanan Faydalar } \\
\text { Kapsamında Borçlar }\end{array}$ & 435- Kilit Personele Borçlar & & 166.667 \\
\hline
\end{tabular}

\footnotetext{
${ }^{17} \mathrm{Bu}$ öz kaynak hesabının ne olması gerektiği hususunda standart herhangi bir belirleme yapmamaktadır. Bazı ülkelerde pay bazlı ödemelere ait olduğu açıkça belirlenmiş bir yedek hesabı kullanılmakta, bu hesap yükümlülük ifa edildiğinde sermaye, diğer yedekler veya geçmiş yıllar kârları/zararları ile kapatılmaktadır. Bazı ülkelerde ise işlemin en başında geçmiş yıllar/kâr zararları hesabı kullanılmaktadır (PwC, 2011: 32). Bu örnekte SPK tarafindan belirlenen finansal tablo formatlarında pay bazlı ödemelere mahsus bir yedek hesabına yer verilmediğinden basitlik açısından geçmiş yıllar kârları/zararları hesabının kullanılması tercih edilmiştir.
} 


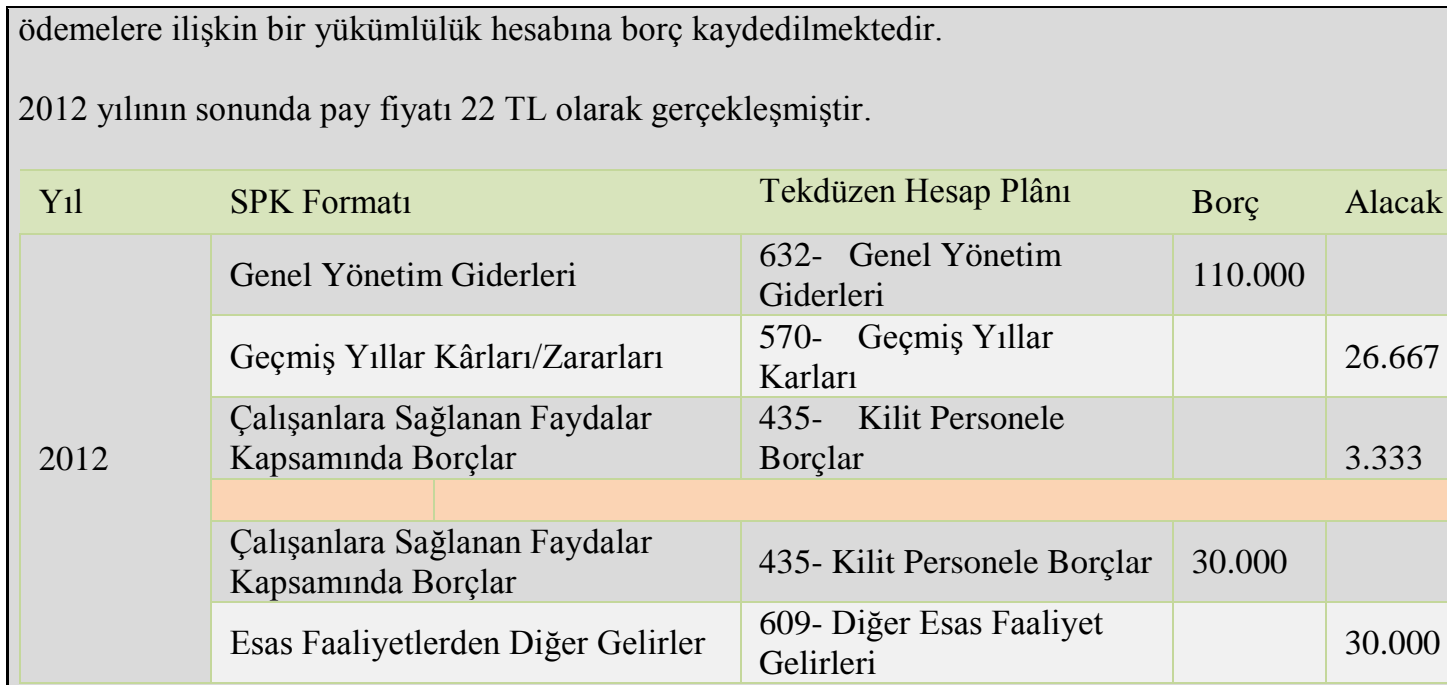

Hak ediş döneminin sonunda 330.000 TL tutarındaki asgarî giderin son kısmı da kaydedilmiş; ancak, bu defa 110.000 TL’lik tutar öz kaynak ve yükümlülük olarak iki ayrı parçaya ayrılarak muhasebeleştirilmiştir. Bunun sebebi, nakdî ödeme seçeneğinin en baştan bu yana geçerli olduğu kabul edilerek hak ediş dönemi sonunda toplam yükümlülük tutarının doğru hesaplanabilmesidir. Buna göre, plânın başından bu yana toplam yükümlülük, geçiş tarihindeki pay fiyatı dikkate alındığında 250.000 TL (25 TL*10.000) olarak hesaplanmaktadır. Dolayısıyla son dönemde bakiye 83.333 TL (250.000 TL166.667 TL) öz kaynaktan yükümlülüğe aktarılarak toplamda 330.000 TL giderin 80.000 TL (110.000 $T L+110.000 T L-166.667 T L+26.667 T L)$ 'i öz kaynakta, 250.000 TL (166.667 TL+83.333 TL)'i yükümlülükte muhasebeleştirilmiş olmaktadır. Bununla birlikte, her dönemin sonunda yükümlülüğün yeniden ölçülmesi gerektiğinden hak ediş dönemi sonundaki 22 TL pay fiyatı esas alınarak yükümlülük için 30.000 TL [(25 TL-22 TL)*10.000)] tutarında ilâve bir düzeltme kaydı yapılmaktadır.

Yöneticinin ödemesini pay olarak almak; şirketin de bu yükümlülüğünü geri alınan paylarla ifa etmek istediği durumda aşağıdaki kayıt yapılarak ödeme plânına ilişkin muhasebeleştirme işlemleri tamamlanmaktadır.

\begin{tabular}{|c|c|c|c|c|}
\hline Y1l & SPK Formatı & Tekdüzen Hesap Plânı & Borç & Alacak \\
\hline \multirow{2}{*}{2012} & $\begin{array}{l}\text { Çalışanlara Sağlanan Faydalar } \\
\text { Kapsamında Borçlar }\end{array}$ & $\begin{array}{l}\text { 435- Kilit Personele } \\
\text { Borçlar }\end{array}$ & 220.000 & \\
\hline & Geri Alınmış Paylar (-) & $\begin{array}{l}\text { 504- Geri Alınmış Hisse } \\
\text { Senetleri (-) }\end{array}$ & & 220.000 \\
\hline
\end{tabular}

Diğer taraftan, şartlar gereği çalışana ödenen söz konusu payların (örneğin 24 TL fiyattan) geri alınması hâlinde ise aşağıdaki kaydın yapılması gerekmektedir:

\begin{tabular}{|c|c|c|c|c|}
\hline Y1l & SPK Format1 & Tekdüzen Hesap Plânı & Borç & Alacak \\
\hline \multirow{3}{*}{2012} & Geri Alınmış Paylar (-) & $\begin{array}{l}\text { 504- Geri Alınmış Hisse } \\
\text { Senetleri (-) }\end{array}$ & 220.000 & \\
\hline & Genel Yönetim Giderleri & $\begin{array}{l}\text { 632- Genel Yönetim } \\
\text { Giderleri }\end{array}$ & 20.000 & \\
\hline & Nakit ve Nakit Benzerleri & 102- Bankalar & & 240.000 \\
\hline
\end{tabular}

Böylece, geri alınan payların değeri kadar daha az gider oluşmuştur.

Kaynak: IFRS 2-Implementation Guidance.

\footnotetext{
${ }^{18}$ Basitlik açısından geri alınan paylar maliyet yöntemiyle muhasebeleştirilmiştir.
} 


\subsubsection{Pay Geri Alımı İşlemlerinin Nakit Akış Tablosunda Sunulması}

TMS 7 - "Nakit Akış Tabloları" standardında şirketlerin nakit akış tablosu hazırlamaları ve bir raporlama dönemine ait nakit akışlarını işletme, yatırım ve finansman faaliyetlerine dayalı bir biçimde sınıflandırarak raporlamaları zorunlu tutulmuştur (TMS/IAS 7: Para. 3, 10). Şirketler gelir getirici ana faaliyetleriyle iştigal ederek işletme faaliyetlerinden; ileride kendisine nakit akışı yaratacak varlıklara yatırım yaparak yatırım faaliyetlerinden; bunların gerçekleştirilebilmesi için gerekli olan kaynağı temin ederek finansman faaliyetlerinden nakit akışı elde etmektedir. Pay geri alımına bağlı nakit akışları ise finansman faaliyetlerinden kaynaklanan nakit akışı başlığı altında sınıflandırılarak sunulmalıdır (TMS/IAS 7: Para. 17).

Diğer taraftan, çalışanlara yapılan ödemelerden kaynaklanan nakit çıkışlarının işletme faaliyetlerinden kaynaklandığı kabul edilse de (TMS/IAS 7: Para. 14), geri alınan payların çalışanlara verilerek ödeme yükümlülüğünün yerine getirilmesine kadarki süre zarfinda, pay geri alımı için yapılmış bulunan nakit çıkışlarının finansman faaliyetinden kaynaklandığı değerlendirilmektedir (Ernst\&Young, 2013: Bölüm 38/4.4.5.).

\subsubsection{Geri Alınan Payların Pay Başına Kazanç Oranını Etkilemesi}

Pay başına kazanç (PBK) oranı TMS 33 - "Hisse Başına Kazanç" standardında, "şirketin kazanç veya zararının (pay) ilgili döneme ait pay sayısının zaman ağırlıklı ortalamasına (payda) bölünmesiyle hesaplanan finansal bir oran olarak" tanımlanmıştır (TMS/IAS 33: Para. 10). Oranın "payda” kısmına odaklanan (TMS/IAS 33: Para. 1) standarda göre amaç, paydada, sermaye tutarını temsil eden payların adedinde dönem boyunca değişiklik olma olasılığının doğru bir şekilde yansıtılabilmesidir.

Söz konusu standart uyarınca, PBK oranının hesaplanmasında oranın paydasının, dönem içinde yapılan geri alım işlemleri nedeniyle dolaşımdaki pay adedinin azaldığı göz önünde bulundurularak düzeltilmesi (TMS/IAS 33: Para. 20) gerekmektedir. Bu düzeltmenin paydayı teşkil eden ağırlıklı ortalama pay sayısını azaltacağı; karşılığında da, PBK oranını artıracağı açıktır.

Diğer taraftan, pay geri alımlarının PBK oranının paydası üzerindeki etkilerinin adî ve sulandırılmış pay sayısı bakımından farklı boyutları bulunmaktadır.

\subsubsection{Geri Alınan Payların Adî Pay Başına Kazanç Oranına Etkisi}

TMS 33 uyarınca adî pay sayısının ağırlıklı ortalamasının hesaplanabilmesi için, dönem başındaki adî pay sayısının dönem içinde geri alınan adî pay sayısının zaman ağırlıklı etkilerine göre düzeltilmesi gerekmektedir. 


\section{Örnek muhasebe uygulaması: pay geri alımının adî PBK oranı üzerindeki etkileri}

XYZ A.Ş.'nin dönem başında (01.01.2013) dolaşımdaki pay sayısı 100.000 adettir. Şirket dönem içinde (01.09.2013) 10.000 adet payını geri almıştır. Dönem sonunda (31.12.2013) şirket 200.000 TL net dönem kârı elde etmiştir.

\begin{tabular}{|l|r|r|r|}
\hline & $\begin{array}{l}\text { Dolaşımdaki } \\
\text { Pay Sayısı (A) }\end{array}$ & $\begin{array}{l}\text { Dolaşımda } \\
\text { Bulunma } \\
\text { Zamanı (B) }\end{array}$ & A*B \\
\hline 1.1.2013 itibarıyla pay sayısı & 100.000 & $12 / 12$ & 100.000 \\
\hline Geri alınan pay sayısı (1.9.2013) & $(10.000)$ & $4 / 12$ & $(3.333)$ \\
\hline Zaman ağırlıklı ortalama pay sayısı (31.12.2013) & & & 96.667 \\
\hline
\end{tabular}

Şirketin geri alım yaptığı tarihten dönem sonuna kadar geçen süre zarfında dolaşımdaki adî pay sayısında meydana gelen azalmanın aslında tüm dönem için ne kadar etki ettiğinin tespit edilmesi gerekmektedir. Buna göre, normalde 12 ay boyunca dolaşımda bulunması beklenen 100.000 adet $(100.000 * 12 / 12)$ pay, geri alımın dolaşımdaki pay sayısında yarattığ 4 aylık azalmanın tüm döneme olan 3.333 adetlik $(10.000 * 4 / 12)$ etkisiyle 96.667 adede düşmektedir. Bu hesaplama aşağıdaki şekilde de yapilabilmektedir:

\begin{tabular}{|l|r|l|r|}
\hline & $\begin{array}{l}\text { Dolaşımdaki } \\
\text { Pay Sayısı (A) }\end{array}$ & $\begin{array}{l}\text { Dolaşımda } \\
\text { Bulunma } \\
\text { Zamanı (B) }\end{array}$ & A*B \\
\hline 1.1.2013 itibarıyla pay sayısı & 100.000 & $8 / 12$ & 66.667 \\
\hline Geri alım sonrası pay sayısı (1.9.2013) & 90.000 & $4 / 12$ & 30.000 \\
\hline Zaman ağırlıklı ortalama pay sayısı (31.12.2013) & & & 96.667 \\
\hline
\end{tabular}

Geri alım işlemleri sonucunda PBK oranında artış yaşanmakla birlikte, geri alınan payların zaman ağırlıklı etkisi dikkate alınmadan yapılacak bir PBK oranı hesaplaması yanlış sonuç verecektir. Bu uygulama aşağıda gösterilmektedir:

\begin{tabular}{|c|c|c|c|}
\hline & $\begin{array}{l}\text { Net Dönem Kârı } \\
\text { (TL) }\end{array}$ & Dolaşımdaki Adî Pay Sayısı & $\begin{array}{c}\text { BK } \\
\text { (TL) }\end{array}$ \\
\hline Geri alım öncesi & \multirow{4}{*}{200.000} & 100.000 & \\
\hline Geri alım sonrası & & & \\
\hline Zaman Ağırlıksız & & 90.000 & ,22 \\
\hline Zaman Ağırlıklı & & 96.667 & ,07 \\
\hline
\end{tabular}

Kaynak: IAS 33-Illustrative Examples.

\subsubsection{Geri Alınan Payların Sulandırılmış Pay Başına Kazanç Oranına Etkisi}

Sulandırılmış PBK oranı, şirketin adî PBK oranının sulandırma potansiyeli olan adî paylara göre düzeltilmesiyle hesaplanmaktadır. Potansiyel adî paylar, yalnızca anılan payların adî paylara dönüşümünün PBK oranını azaltması durumunda, sulandırma etkisine sahiptir (TMS/IAS 33: Para. 41).

Potansiyel adî paylar, sahibine adî paya sahip olma hakkı vermekle birlikte hâlihazırda mevcut olmadıkları (örneğin, ihraç edilmedikleri için) için adî paylar arasında yer 
almamaktadır. Söz konusu paylara örnek olarak, pay opsiyonları ve varantlar, paya dönüştürülebilir finansal araçlar, şarta bağlı olarak ihraç edilebilen paylar ve ödemesi adî pay alımı veya nakit ile yapılabilen sözleşmeler verilebilir (Alper ve P. Arsoy, 2009: 63).

Şirketler tarafından çalışanlarına ödeme plânları kapsamında yazılan opsiyonlar adî payların dönem içindeki ortalama piyasa fiyatının ilgili opsiyonun kullanım değerini aşması durumunda, bir başka deyişle, kârda olmaları durumunda adî PBK oranını sulandırma etkisine sahiptir. Bu nedenle, PBK oranı, sulandırma etkisi olan opsiyonların kullanıldığı farz edilerek ayrıca hesaplanmalıdır [TMS/IAS 33: Para. 32/(b)]. Buna göre, "dönem içinde opsiyonların içerdiği adî pay sayısı ile opsiyonun kullanımına bağlı olarak ortalama piyasa fiyatından ihraç edilmiş sayılan adî pay sayısı arasındaki fark, bedelsiz olarak ihraç edilmiş adî paylar olarak kabul edilmektedir” (TMS/IAS 33: Para. 45).

\section{Örnek muhasebe uygulaması: pay geri alımının sulandırıımış PBK oranı üzerindeki etkileri}

XYZ A.Ş.'nin dönem başında (01.01.2013) dolaşımdaki pay sayısı 500.000 adettir. Şirket, çalışanları için hazırladığı ödeme plânı kapsamına 100.000 adet pay içeren pay opsiyonlarını da dâhil etmiştir. Dönem boyunca ortalama pay fiyatı $20 \mathrm{TL}$ olarak gerçekleşmiştir. Pay opsiyonlarının kullanım fiyatı ise 15 TL'dir. Dönem sonunda (31.12.2013) şirket 1.200.000 TL net dönem kârı elde etmiştir. PBK oranı aşağıdaki gibi hesaplanmaktadır.

\begin{tabular}{|l|l|l|r|}
\hline $\begin{array}{l}\text { Net Dönem } \\
\text { Kârı }\end{array}$ & $\begin{array}{l}\text { Dolaşımdaki } \\
\text { Pay Adedi }\end{array}$ & $\begin{array}{l}\text { Adî } \\
\text { PBK }\end{array}$ & $\begin{array}{l}\text { Sulandırılmış } \\
\text { PBK }\end{array}$ \\
\hline \multirow{2}{*}{1.200 .000} & 500.000 & 2,4 & 2,29 \\
\cline { 2 - 4 } & 525.000 & & \\
\hline
\end{tabular}

İlk hesaplama opsiyonun sulandırıcı etkisi olup olmadığına bakılmaksızın adî PBK oranının tespitine yöneliktir. İkinci hesaplamada ise, sulandırma potansiyeli olan adî payları içeren opsiyonlar dikkate alınmaktadır. Dönem sonunda opsiyonların kullanım fiyatının payların piyasa fiyatından düşük olması nedeniyle opsiyonlar kârda (in-the-money) olduklarından kullanılacağının varsayılması gerekmektedir. Buna göre, opsiyonlar kullanıldığında şirketin yükümlülüğünü yerine getirebilmesi için karşılığında pay ihracı yapması beklenmektedir. Örnekte, şirketin 1.500.000 TL (100.000*15 TL) değerinde opsiyon kullanımı karşılığında yapacağı sermaye artırımının miktarı 75.000 (1.500.000 TL/20 TL) adet olarak hesaplanmaktadır. Sulandırılmış PBK oranının hesabında bu miktarın piyasadan geri alınıp çalışanlara verileceği kabulüyle hareket edilmektedir. Böylece, esasında 100.000 adet adî pay içeren pay opsiyonları 75.000 adet kadar azaltılarak 25.000 miktarında bedelsiz pay ihracı yapılmış gibi muamele yapılmak suretiyle adî pay sayısı 525.000 (500.000+100.000-75.000) olarak hesaplanmaktadır.

Kaynak: IAS 33-Illustrative Examples.

\subsubsection{Geri Alım İşlemlerinin İlişkili Taraflarla Yapılması}

TMS 24 - "İlişkili Taraf Açıklamaları" standardı, payların şirketin yöneticileri, hâkim ortakları, grup şirketleri vb. ilişkili taraflarından (TMS/IAS 24: Para. 13-24) geri alınması hâlinde, geri alınan paylarla ilgili açıklamaların, ilişkili taraflara yönelik açıklamaları da 
kapsamasını (TMS/IAS 32: Para. 34) gerektirmektedir. İlişkili taraflarla yapılan pay geri alımı işlemlerine, şirketin kendi paylarını bağlı ortaklığından, bedelli, bedelsiz, rehin veya alacaklarının karşılığı olarak geri alması veya şirketin üst yönetimine yapılacak ödemelerde kullanılmak amacıyla geri alım yapılması örnek verilebilir. Bu gibi durumlarda, ilişkili tarafla ilgili bilgiler ile ilişkinin niteliğinin ve içeriğinin geri alınan pay tutarları vb. standart bilgilere ilâveten ayrıca açıklanması zorunludur.

\subsubsection{Konsolide Finansal Tablolarda Geri Alınan Paylar}

Bağlı ortaklıkların kendi paylarını geri almaları, özünde ana ortaklığın bağlı ortaklıktaki haklarında gerçekleşen bir değişimi ifade etmekte; bir başka deyişle, ana ortaklığın bağlı ortaklık nezdindeki kontrol gücü olmayan payları satması anlamına gelmektedir (Bellandi, 2012: 152). Buna göre, bir ana ortaklığın bağlı ortaklığındaki kontrol gücünü artırmanın bir yolunun "bağlı ortaklığının kendi paylarını geri almalarını sağlamak" olduğu söylenebilir. Bir şirketin kendi paylarını, ortağı olan bir başka şirketin kontrol gücü elde edebilmesi amacıyla geri alması hâlinde, bu işlem TFRS - 3 "İşletme Birleşmeleri”" (IFRS 3 - "Business Combinations) standardı kapsamında bir birleşmedir (TFRS/IFRS 3: Para. 43).

Bağlı ortaklığın kendi paylarını geri alması hâlinde, konsolide finansal tabloların hazırlanması sürecinde, ana ortaklığın bağlı ortaklığının öz kaynaklarındaki haklarının pay geri alımından önceki ve sonraki değerinin karşılaştırılması ve aradaki fark tespit edilmek suretiyle bağlı ortaklık yatırımının kayıtlı değerinde ve öz kaynaklarında bu fark kadar düzeltme yapılması gerekmektedir.

\section{Örnek muhasebe uygulaması: bağlı ortaklığın geri aldığı paylarının konsolide tablolara etkisi (bin TL)}

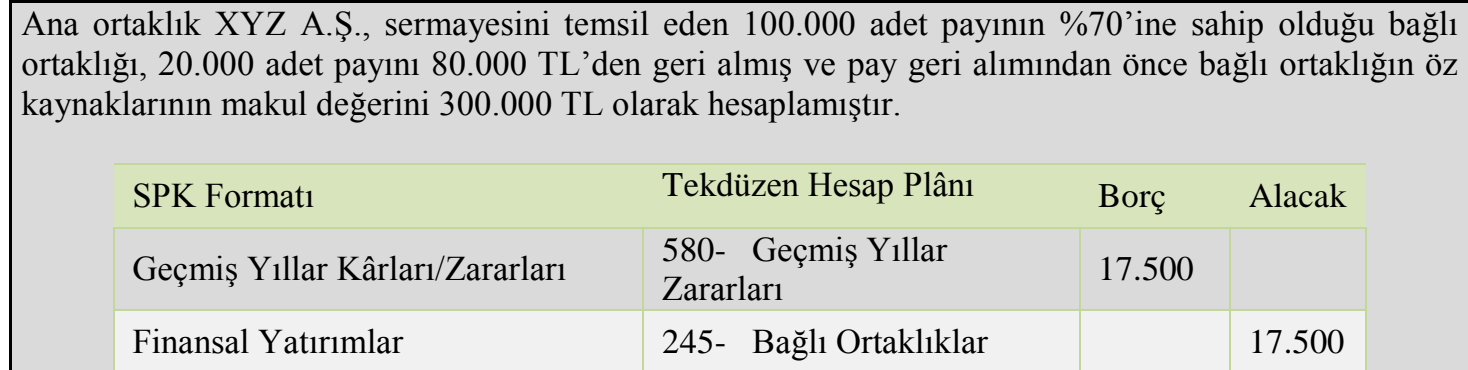

SPK Format1

Geçmiş Yıllar Kârları/Zararları

Finansal Yatırımlar

Tekdüzen Hesap Plânı

580- Geçmiş Yıllar

Zararları

245- Bağlı Ortaklıklar

Borç Alacak

17.500

17.500

Pay geri alımından sonraki dönemde şirketin bağlı ortaklıktaki pay oranının $\% 87,5{ }^{\prime}{ }^{19}$ çıkması; bağlı ortaklığın öz kaynaklarının makul değerinin ise, 220.000 TL'ye ${ }^{20}$ düşmesi nedeniyle, konsolide

\footnotetext{
${ }^{19}$ [Pay geri alımından önce sahip olunan pay adedi (70.000)] / [Pay geri alımından sonra sahip olunan pay adedi (80.000)].

${ }^{20}$ [Bağlı ortaklığın öz kaynaklarının pay geri alımından önceki makul değeri (300.000 TL)] - [Pay geri alımı için ödenen bedelin makul değeri (80.000 TL)].
} 
finansal tablolar hazırlanırken şirkete ait öz kaynakların ve bağlı ortaklık yatırımının kayıtlı değerinde $(17.500 \mathrm{TL})^{21}$ tutarında düzeltme yapılması gerekmektedir ${ }^{22}$.

Kaynak: (Fischer vd., 2012: 448)

Diğer taraftan, bağlı ortaklıkların şirket paylarını satın almaları grup açısından şirketin kendi paylarını geri alması hükmündedir (TMS/IAS 32: Para. 33).

\section{SONUÇ}

Uluslararası arenada pay geri alım işlemlerinin şirketler açısından önemi giderek artmakta ve bunlara ilişkin muhasebe ve raporlama uygulamaları bu gidişata ayak uydurabilmek amaciyla sürekli gelişim göstermektedir. Türkiye'de ise, söz konusu işlemlerin gerçekleştirilebilmesine yönelik hukukî altyapının görece yeni tesis edilmiş olması, şirketlerin geri alım işlemlerine karşı çekimser kalmasına neden olabilecektir. $\mathrm{Bu}$ nedenle, TMS/TFRS'nin pay geri alımlarıyla ilgili hükümlerinin bilinmesinin şirketlerin bu konudaki motivasyonunu artırabileceği düşünülmektedir.

Her şeyden önce, pay geri alım işlemlerinin ortaklar arasında gerçekleştirildiği düşüncesinden hareketle TMS/TFRS kapsamında öz kaynaklarda muhasebeleştirilmesi gerektiği hususunun göz önünde bulundurulmasında fayda görülmektedir. İlgili muhasebe işlemleri, maliyet, nominal değer ve geri çekilmiş sayma yöntemlerinden biri takip edilerek yapılabilecek olmakla birlikte; maliyet yönteminin şirketlere, payların ilk ihracında oluşturulan hesapların yeniden çalıştırılmasına ihtiyaç olmadığı dikkate alınarak, büyük kolaylık sağlayacağı; bu nedenle de geri alınan payların itfa edilmesine yönelik bir niyet bulunmadıkça maliyet yönteminin kullanılmasının uygun olacağı düşünülmektedir.

Ancak, pay geri alımlarının, etkilerinin öz kaynaklarla sınırlı olmadığı; çalışanlara yapılan ödemelerde kullanılması, şirketin nakit durumunu ilgilendirmesi, menfaat çatışmalarına sebep olabilmesi ve pay başına kazanç oranını etkilemesi vb. özellikli hususlar itibarıyla da şirketler açısından önem arz ettiği göz önünde bulundurulmalıdır.

$\mathrm{Bu}$ çerçevede, çalışmanın söz konusu işlemlerin finansal tablolara olan çok yönlü etkilerinin anlaşılabilmesine yardımcı olacağına inanılmaktadır.

\footnotetext{
${ }^{21}$ [Pay geri alımı sonrasında ana ortaklığın bağlı ortaklıktaki haklarının makul değeri $(220.000 \mathrm{TL} * \% 87,5=$ $192.500 \mathrm{TL})$ ] - [Pay geri alımı öncesinde ana ortaklığın bağlı ortaklıktaki haklarının makul değeri (300.000 TL * $\% 70=210.000 \mathrm{TL})]$.

${ }^{22}$ Bu düzeltme ana ortaklığa ait öz kaynağın (pay ihraç primi ve/veya geçmiş yıllar zararı) borçlandırılması, konsolidasyon sırasında elimine edilecek bağlı ortaklık yatırımının kayıtlı değerinin de alacaklandırılması şeklinde yapılacaktır. Farkın pozitif çıkması hâlinde ise ana ortaklığın öz kaynaklarında pay ihraç primi hesabında düzeltme yapılması söz konusu olmaktadır.
} 


\section{KAYNAKLAR}

Alper, D., \& Poroy Arsoy, A. (2009), "Sulandırmanın Hisse Başına Kazanç Hesaplamasına Etkileri”, Malî Çözüm Dergisi, 94, ss.59-78.

Bellandi, F. (2012). Dual Reporting for Equity and Other Comprehensive Income under IFRS and US GAAP. West Sussex, Birleşik Krallık: John Wiley\&Sons Ltd.

Bragg, S. M. (2010). GAAP: Interpretation and Application of Generally Accepted Accounting Principles. Hoboken, New Jersey, ABD: John Wiley\&Sons, Inc.

Dhanani, A., \& Roberts, R. (2009). Corporate Share Repurchases: The Perceptions and Practices of UK Financial Managers and Corporate Investors. Edinburgh: The Institute of Chartered Accountants of Scotland.

Epstein, B. J., \& Jermakowicz, E. K. (2008). Interpretation and Application of International Financial Reporting Standards. Hoboken, New Jersey, ABD: John Wiley\&Sons, Inc.

Ernst\&Young. (2013). International GAAP 2013: Generally Accepted Accounting Practice Under International Financial Reporting Standards. West Sussex, Birleşik Krallık: John Wiley\&Sons Ltd.

Fischer, P. M., Taylor, W. J., \& Cheng, R. H. (2012). Advanced Accounting (11 b.). Mason, Ohio, ABD: South-Western Cengage Learning.

Flood, J. M. (2014). GAAP: Interpretation and Application of Generally Accepted Accounting Principles. Hoboken, New Jersey, ABD: John Wiley\&Sons, Inc.

Kooli, M., \& L'Her, J.-F. (2010, ), "Dividends versus Share Repurchases Evidence from Canada: 1985-2003”, The Financial Review, 45(1), pp. 57-81.

MacGuigan, J. R., Kretlow, W. J., \& Moyer, R. C. (2009). Contemporary Corporate Finance (11 b.). Mason, Ohio, ABD: South-Western Cengage Learning.

Mieczysław, K. (2011), “ Share Repurchases As A Form of Payout For Shareholders”, eFinance: Financial Internet Quarterly, 7(4), pp. 37-54.

PwC. (2011). A Practical Guide to Share-Based Payments. Pricewaterhouse Coopers.

Stickney, C. P., Weil, R. L., Schipper, K., \& Francis, J. (2009). Financial Accounting: An Introduction to Concepts, Methods, and Uses (13 b.). Mason, Ohio, ABD: SouthWestern Cengage Learning.

TMS/TFRS Finansal Raporlamaya İlişkin Kavramsal Çerçeve, 27.01.2011 tarih ve 27828 sayılı Resmî Gazete / "The Conceptual Framework for Financial Reporting”, http://eifrs.ifrs.org/eifrs/Menu

TFRS 2 - "Hisse Bazlı Ödemeler", 31.03.2006 tarih ve 26125 sayılı Resmî Gazete / IFRS 2 "Share-based Payment”, http://eifrs.ifrs.org/eifrs/Menu

TFRS 3 "İşletme Birleşmeleri, 26/08/2010 tarih ve 27684 sayılı Resmî Gazete / IFRS 3 “Business Combinations”, http://eifrs.ifrs.org/eifrs/Menu 
TFRS 10 - "Konsolide Finansal Tablolar”, 28.10.2011 tarihli ve 28098 sayılı Resmî Gazete / IFRS 10 - “Consolidated Financial Statements”, http://eifrs.ifrs.org/eifrs/Menu

TMS 7 - "Nakit Akış Tabloları", 18.01.2005 tarih ve 25704 sayılı Resmî Gazete / IAS 7 "Statement of Cash Flows", http://eifrs.ifrs.org/eifrs/Menu

TMS 24 - "İlişkili Taraf Açıklamaları", 31.12.2005 tarih ve 26040 sayılı Resmî Gazete / IAS 24 - "Related Party Disclosures”, http://eifrs.ifrs.org/eifrs/Menu

TMS 32 - "Finansal Araçlar: Sunum", 28.10.2006 tarih ve 26330 sayılı Resmî Gazete / IAS

32 - "Financial Instruments: Presentation”, http://eifrs.ifrs.org/eifrs/Menu

TMS 33 - "Hisse Başına Kazanç", 28.03.2006 tarih ve 26122 sayılı Resmî Gazete / IAS 33 “Earnings Per Share”, http://eifrs.ifrs.org/eifrs/Menu

TMS 39 - "Finansal Araçlar: Muhasebeleştirme ve Ölçme", 03.11.2006 tarih ve 26335 sayılı Resmî Gazete / IAS 39 "Financial Instruments: Recognition and Measurement”, http://eifrs.ifrs.org/eifrs/Menu 
